\title{
Statistical physical and nutrient optimization of bioplastic polyhydroxybutyrate production by Cupriavidus necator
}

\author{
A. Aramvash • Z. Akbari Shahabi - S. Dashti Aghjeh • \\ M. D. Ghafari
}

Received: 16 September 2014/Revised: 29 December 2014/ Accepted: 27 January 2015/Published online: 4 February 2015

(C) Islamic Azad University (IAU) 2015

\begin{abstract}
Polyhydroxyalkanoates are biodegradable polymer materials that accumulate in numerous bacteria. The polyhydroxybutyrate is the most common type of polyhydroxyalkanoates, which potentially serves as precursor for bioplastic production. The most extensively studied polyhydroxybutyrate producing bacteria is Cupriavidus necator due to its capability to accumulate large amounts of this biopolymer in simple culture medium. Accumulation of polyhydroxyalkanoates granules in the cytoplasm of $C$. necator significantly depended on $\mathrm{pH}$, aeration, carbon sources, nitrogen sources, and minerals in the culture medium. In the present study, the effect of both nutritional and physical variables on polyhydroxybutyrate production was investigated in order to optimize these conditions. At first, on the basis of one-factor-at-a-time experiments, fructose and ammonium chloride were found to be the most suitable sources of carbon and nitrogen for biopolymer production. Then the most significant factors affecting granules accumulation were recognized as fructose, agitation speed, $\mathrm{KH}_{2} \mathrm{PO}_{4}$, and initial $\mathrm{pH}$ using the Plackett-Burman and central composite design. ANOVA analysis showed significant interaction between fructose and agitation speed. After optimization of the medium,
\end{abstract}

A. Aramvash $(\bowtie) \cdot$ S. Dashti Aghjeh

Department of Bioscience and Biotechnology, Malek-Ashtar University of Technology, P.O. Box 16765-3454, Tehran, Iran e-mail: Aramvash@ibb.ut.ac.ir

\section{Z. Akbari Shahabi}

Biotechnology Group, Department of Chemical Engineering, Iran University of Science and Technology, Tehran, Iran

\section{D. Ghafari}

Microbiology Group, Department of Biology,

Shahed University, Tehran, Iran compositions for polyhydroxybutyrate production were determined as follows: fructose $35 \mathrm{~g} / \mathrm{L}, \mathrm{KH}_{2} \mathrm{PO}_{4} 1.75 \mathrm{~g} / \mathrm{L}$, $\mathrm{MgSO}_{4} \cdot 7 \mathrm{H}_{2} \mathrm{O} 1.2 \mathrm{~g} / \mathrm{L}$, citric acid $1.7 \mathrm{~g} / \mathrm{L}$, trace element $10 \mathrm{~mL} / \mathrm{L}$, initial $\mathrm{pH}=7$, and agitation speed $175 \mathrm{rpm}$. Under this optimal culture conditions, the maximum yield of PHB was $7.48 \mathrm{~g} / \mathrm{L}$. The present strategies included in this study could be used for PHB production by this bacterium. These results are the highest values of PHB ever obtained from batch culture of $C$. necator reported so far.

Keywords Biopolymer - Optimization - PlackettBurman · Polyhydroxyalkanoates · Response surface methodology

\section{Introduction}

A large body of evidence has shown that plastics can persist in the environment for hundreds of years often as harmful microscopic particles that are known to be dangerous to the environment, especially for marine ecosystems (Galgani et al. 2000; Mumtaz et al. 2010). They are also produced from petrochemical sources that may be depleted and take millions of years to be renewed. Recently, these negative environmental impacts have increased concern of the global community around the world (Gregory 2009). However, there are several attempts to remove toxicity and pollution of water and land (Colak et al. 2009, 2011); some research is focusing increasingly on the development of environmental friendly methods (Gupta et al. 2013) for the production of eco-friendly materials that combine the desired functionality during use and rapid degradation after disposal as an alternative to conventional nondegradable materials. Bioplastics fit this context and are generated from renewable natural sources 
and are often biodegradable and nontoxic (Poirier 1999; Flieger et al. 2003). They can be produced by biological systems or chemically synthesized from biological materials (Flieger et al. 2003).

Polyhydroxyalkanoates (PHAs) are thermoplastic biopolymers that accumulate in wide range of microorganisms under stress conditions (Chen 2005; Khanna and Srivastava 2005). In recent years, PHAs have attracted increasing attention because they could be substitutes for conventional plastics (such as polyolefins), which can reduce petroleum consumption and alleviate environmental impact caused by plastic waste (Ivanov et al. 2014). These bioplastics have application in agriculture, medicine, pharmaceutical, and packaging (Chen and Qiong 2005; Wang et al. 2005). The most widely produced microbial PHA is polyhydroxybutyrate (PHB). Cupriavidus necator has remarkable capacity for accumulating PHB up to $90 \%$ of the cellular dry weight under phosphorous or nitrogen limitation (Liu et al. 2005; Shang et al. 2003).

It is obvious that the optimization of media parameters plays an important role in increasing the production of any metabolite in setting up of any microbial fermentation process. The one-factor-at-a-time method optimizes medium by changing one factor of the medium and keeps all other parameters constant. However, this method is timeconsuming, and interaction among the medium component cannot be studied (Mu et al. 2009). The limitation of such method can be avoided by using statistical experimental design, a powerful and useful tool, which can allow explaining interactions between the different variables and decreasing the process variability (Frey et al. 2003). The most popular choices are the Plackett-Burman design (PBD) and the central composite design (CCD), along with the response surface analysis (Liu et al. 2005; Xu et al. 2008). The response surface methodology (RSM) is a kind of statistical technique for designing experiments, evaluating the relative significance of several independent variables, and determining the optimum conditions for desirable responses (Anderson-Cook et al. 2009). There are some examples of successful optimization of medium for microbial production of PHB in various microorganisms. These studies take into account the effect of different media components on maximizing the productivity of PHB using various nitrogen sources (i.e., urea and $\mathrm{NH}_{4} \mathrm{Cl}$ ) and carbon sources (i.e., sucrose, glucose, acetate, malt, soya, sesame, molasses, bagasse, and gluconic acid) (Md Din et al. 2014; Arun et al. 2006; Sandhya et al. 2013; Wei et al. 2011). $\mathrm{KH}_{2} \mathrm{PO}_{4}, \mathrm{Na}_{2} \mathrm{HPO}_{4}$, and $\mathrm{MgSO}_{4} \cdot 7 \mathrm{H}_{2} \mathrm{O}$ and physical factors like temperature, $\mathrm{pH}$, and agitation speed which playing significant role in PHB accumulation were also optimized in some microorganisms using RSM for enhanced PHB production (Khanna and Srivastava 2005; Cavalheiro, et al. 2009; De Almeida et al. 2010). However, there are few reports, which focused on the effect of physical process variables along with nutrient constituents on PHB production (Khosravi Darani et al. 2004). In this study at first, the one-factor-at-a-time experiments were used to select the optimal carbon and nitrogen sources. Then, Plackett-Burman design was used to identify the most important factors on PHB production, which shows physical variables (i.e., agitation speed) are as important as medium components, because the redox state of the cells is known to affect the synthesis of PHB (de Almeida et al. 2010). Moreover, CCD and the analysis of response surface methodology (RSM) were carried out to optimize effective factors including fructose, $\mathrm{KH}_{2} \mathrm{PO}_{4}$, initial $\mathrm{pH}$, and agitation speed for enhanced PHB production in batch cultivation of $C$. necator ATCC 17699. This study was conducted during September 2013 to April 2014 at Laboratory of Biochemistry, Department of Bioscience and Biotechnology, Malek-Ashtar University of Technology, Tehran, Iran.

\section{Materials and methods}

Microorganism strain and inoculum preparation

Cupriavidus necator ATCC 17699 was obtained from the Persian Type Culture Collection for the production of PHB. The PHB-producing capability of the organism was confirmed by Sudan Black staining method (Burdon 1946). The bacteria were maintained on LB agar slants at $4{ }^{\circ} \mathrm{C}$. For inoculums preparation, the cells were grown on a LB medium for $10 \mathrm{~h}$ at $30{ }^{\circ} \mathrm{C}$ on a shaker at $200 \mathrm{rpm}$; stock cultures were maintained at $-20{ }^{\circ} \mathrm{C}$ in $5-\mathrm{mL}$ vials containing $4 \mathrm{~mL}$ of basal medium and $1 \mathrm{~mL}$ of glycerol solution until use.

\section{Culture condition}

The composition of the basal mineral salt medium (MSM) used in this study was as follow: $\left(\mathrm{NH}_{4}\right)_{2} \mathrm{SO}_{4} 2.0 \mathrm{~g} / \mathrm{L}$, $\mathrm{KH}_{2} \mathrm{PO}_{4} 1.54 \mathrm{~g} / \mathrm{L}, \mathrm{MgSO}_{4} \cdot 7 \mathrm{H}_{2} \mathrm{O} 1.2 \mathrm{~g} / \mathrm{L}$, Citric acid $1.7 \mathrm{~g} /$ $\mathrm{L}$, trace metal solution $10 \mathrm{~mL} / \mathrm{L}$ (Kim et al. 1994a). The trace element stock solution composed of $\mathrm{ZnSO}_{4} \cdot 7 \mathrm{H}_{2} \mathrm{O}$ $2.25 \mathrm{mg} / \mathrm{L}, \mathrm{FeSO}_{4} \cdot 7 \mathrm{H}_{2} \mathrm{O} 10 \mathrm{mg} / \mathrm{L}, \mathrm{CaCl}_{2}\left(2 \mathrm{H}_{2} \mathrm{O}\right) 2 \mathrm{mg} / \mathrm{L}$, $\mathrm{Na}_{2} \mathrm{~B}_{4} \mathrm{O}_{7}\left(7 \mathrm{H}_{2} \mathrm{O}\right) \quad 0.23 \mathrm{mg} / \mathrm{L}, \quad\left(\mathrm{NH}_{4}\right)_{6} \mathrm{Mo}_{7} \mathrm{O}_{24} \quad 0.1 \mathrm{mg} / \mathrm{L}$, $\mathrm{CuSO}_{4} \cdot\left(5 \mathrm{H}_{2} \mathrm{O}\right) 1 \mathrm{mg} / \mathrm{L}, \mathrm{MnSO}_{4}\left(5 \mathrm{H}_{2} \mathrm{O}\right) 0.6 \mathrm{mg} / \mathrm{L}$, and $\mathrm{HCl}$ $35 \% 10 \mathrm{~mL} / \mathrm{L}$ (Kim et al. 1994b). Glucose was used as carbon source in concentration of $20 \mathrm{~g} / \mathrm{L}$ for production media and inoculums development. (Glucose was used for initial studies; however, after some experiments, fructose was used as carbon sources for the following experiments). The initial $\mathrm{pH}$ was adjusted to 7.0.

Comparison of different carbon and nitrogen sources was carried out using the media same as described above. 
However, for comparison, different carbon $(20 \mathrm{~g} / \mathrm{L})$ and nitrogen $(2 \mathrm{~g} / \mathrm{L})$ sources at constant concentration were taken.

\section{Analysis of culture biomass and PHB production}

The effect of different incubation time on growth and PHB production was carried out using MSM supplemented with $2 \%$ glucose. $10 \%$ inoculums were added into $100 \mathrm{~mL}$ of production medium and incubated at $200 \mathrm{rpm}, 30{ }^{\circ} \mathrm{C}$ for different time points $(2-70 \mathrm{~h})$. Samples were withdrawn every $2 \mathrm{~h}$ and analyzed for biomass and PHB. These experiments showed that $48 \mathrm{~h}$ is sufficient for harvesting cells, because after $48 \mathrm{~h}$, the cells reach at steady state phase, and at this time, there is maximum $\mathrm{PHB}$ production.

Effect of different carbon sources on growth and PHB production

The experiments were performed one factor at a time. The effect of different carbon sources on growth and PHB production of culture was carried out using MSM media supplemented with different carbon sources (i.e., fructose, glucose, lactic acid, arabinose, sucrose, and lactose) at $20 \mathrm{~g} / \mathrm{L}$. Inoculums were prepared as described above. The flasks were incubated at $200 \mathrm{rpm}$ at $30{ }^{\circ} \mathrm{C}$. Biomass and PHB were estimated in the culture broth after $48 \mathrm{~h}$.

Effect of different nitrogen sources on growth and PHB production

These experiments were done in MSM containing fructose $(20 \mathrm{~g} / \mathrm{L})$ as carbon source and different nitrogen sources ( $2 \mathrm{~g} / \mathrm{L})$ (i.e., ammonium chloride, ammonium sulfate, peptone, tryptone, yeast extract, and urea). The flasks were incubated at $30{ }^{\circ} \mathrm{C}$ and $200 \mathrm{rpm}$. Biomass and PHB were estimated in cell broth after $48 \mathrm{~h}$.

Growth and cell dry weight determination

Cell growth was monitored over time by the measurements of optical density at $600 \mathrm{~nm}\left(\mathrm{OD}_{600}\right)$ using jenway 6310 (Bibby Scientific Limited, Staffordshire, UK).

Cell dry weight determination was done by weighing the dry cell mass obtained as follows. $10 \mathrm{ml}$ culture samples were centrifuged at $10,000 \mathrm{rpm}$ for $15 \mathrm{~min}$ at $4{ }^{\circ} \mathrm{C}$. The pellet was resuspended in distilled water $(10 \mathrm{~mL})$ and centrifuged again for washing. The washed cells were dried at $90{ }^{\circ} \mathrm{C}$ for $24 \mathrm{~h}$ in a hot air oven. The drying was repeated until constant weight was obtained (Jung et al. 2000).

\section{Detection of PHB}

For determining PHB amount, $10 \mathrm{~mL}$ of $98 \%$ sulfuric acid was added to bacterial pellet at $90{ }^{\circ} \mathrm{C}$ for $1 \mathrm{~h}$; PHB crystals in cytoplasm of bacteria were converted into crotonic acid. The absorbance of the solution was measured at $235 \mathrm{~nm}$ in a UV spectrophotometer against sulfuric acid as blank. The amounts of PHB per gram dry weight of bacterial cells were determined using a standard curve of PHB according to Singh and Parmar (2011).

Plackett-Burman design and statistical analysis for optimization

Optimization of medium components for PHB production was performed in two stages. At the first stage, the components that have significant effect on PHB production were identified. At the second stage, the optimum values of these components were determined. A total of seven factors were tested, which were fructose, $\mathrm{KH}_{2} \mathrm{PO}_{4}$, initial $\mathrm{pH}$, ammonium chloride, agitation speed, inoculum size, and trace element solution, with each being represented at two levels, high $(+1)$ and low $(-1)$. A design of 16 experiments was formulated for seven factors using the software. Concentration range for the variables was decided on the basis of other reports for PHB production by $C$. necator (Tripathi et al. 2013; Khanna and Srivastava 2005). The experiments were done in flasks containing $100 \mathrm{~mL}$ media at $200 \mathrm{rpm}$ for $48 \mathrm{~h}$ in duplicate. The factors with confidence level above $95 \%$ are considered the most significant factor that affects PHB production. Four factors (fructose, $\mathrm{KH}_{2} \mathrm{PO}_{4}$, agitation speed, and initial $\mathrm{pH}$ ), screened from Plackett-Burman design, were studied for determining their optimum concentration values for biomass and PHB production.

Response surface methodology

Central composite design using Design Expert (version 7.0.0) software (Stat-Ease Corporation, USA) was used for optimization of the media components, which were found to be important for PHB production according to screening results, based on Plackett-Burman, rest of the factors being kept at a constant level. In this study, the experimental plan consisted of 30 experiments was formulated using the Design Expert software. Experiments were conducted in 250-mL flasks containing $50 \mathrm{~mL}$ of media prepared according to the design. The incubator was set at $30{ }^{\circ} \mathrm{C}$. Responses studied were biomass $(\mathrm{g} / \mathrm{L})$ and PHB $(\mathrm{g} / \mathrm{L})$; at the end of $48 \mathrm{~h}$, three-dimensional (3D) plots were generated to understand the interaction of various factors and then used to find the optimized concentration of the media components affecting the response. A special feature of the 
software point prediction was used to confirm the aboveobtained optimized values.

\section{Results and discussion}

Initial culture and PHB production capacity

Initial cultivation of $C$. necator was performed at $30{ }^{\circ} \mathrm{C}$ and $200 \mathrm{rpm}$ by using the media described in the "Materials and methods." Initial $\mathrm{pH}$ of the media was adjusted to 7.0. Maximum biomass obtained was $1.375 \mathrm{~g} / \mathrm{L}$ with PHB content of $73 \%$ at $48 \mathrm{~h}$ (Fig. 1). The $\mathrm{pH}$ value measured at the end of the cultivation was 7.55 compared with initial value of 7.0. This result shows the medium has relatively strong buffering capacity compared with Khanna and Srivastava (2005) experiment that shows high decrease in $\mathrm{pH}$ from 7 to 5.26 after $48 \mathrm{~h}$. This difference may be due to lower level of carbon source that we used $(20 \mathrm{~g} / \mathrm{L})$ and usage of glucose instead of fructose in initial study. Owen et al. (1991) reported that fructose consumption products lower the $\mathrm{pH}$ of media more than other source of carbohydrates.

The effect of different carbon sources on growth and PHB production

Based on the media used above, a comparative study was carried out by growing the culture in different carbon sources. Finding which carbon source is suitable for $C$. necator for maximum $\mathrm{PHB}$ production gives us insight on using which cost-effective carbon sources are suitable for this strain. Thus, six different carbon sources were selected that coverage the constituents of different cost-effective carbon sources. The results presented in Table 1 indicate

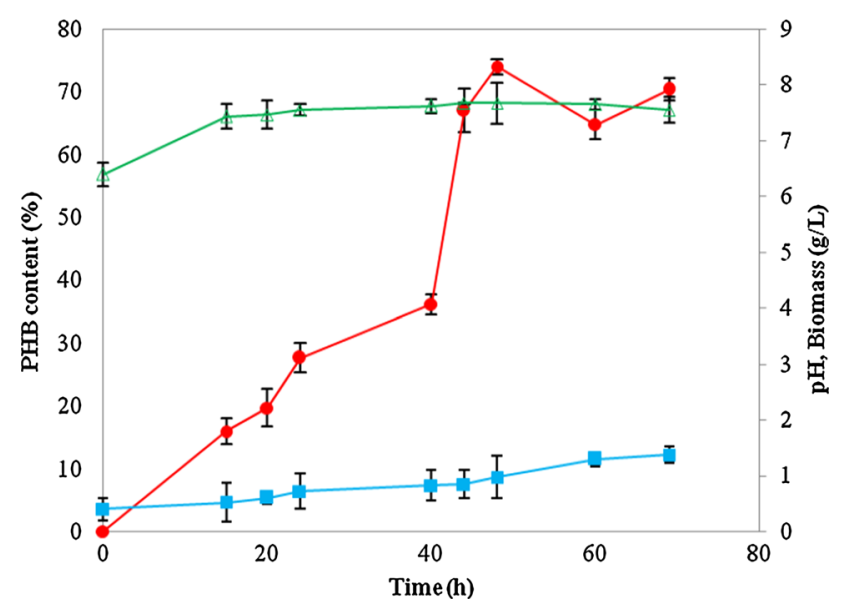

Fig. 1 Biomass, $\mathrm{pH}$, and $\mathrm{PHB}$ content for initial shake flask culture. (red filled circle) PHB content (\%); (blue filled square) Biomass (g/ $\mathrm{L})$; (green triangle) $\mathrm{pH}$
Table 1 Biomass and PHB production by growing the culture in different carbon sources after $48 \mathrm{~h}$

\begin{tabular}{llll}
\hline Carbon source & Biomass $(\mathrm{g} / \mathrm{L})$ & PHB $(\mathrm{g} / \mathrm{L})$ & Final $\mathrm{pH}$ \\
\hline L-Arabinose & 0.96 & 0.1 & 7.5 \\
Lactic acid & 2.18 & 0.66 & 8.2 \\
Glucose & 5.14 & 1.38 & 8.2 \\
Fructose & 4.76 & 2.16 & 8.2 \\
Sucrose & 3.28 & 0.29 & 7.93 \\
Lactose & 2.92 & 0.27 & 8.28 \\
\hline
\end{tabular}

that among the six different combinations of cultures checked for $\mathrm{PHB}$ production, maximum $\mathrm{PHB}$ production was observed for fructose followed by glucose, lactic acid, sucrose, lactose, and arabinose. Table 1 also shows a maximum biomass of $5.14 \mathrm{~g} / \mathrm{L}$ was obtained with $20 \mathrm{~g} / \mathrm{L}$ of glucose. Although the highest growth rate was obtained from glucose, as compared to fructose, the PHB content was less. Because biomass production in glucose and fructose is near and PHB production in fructose is higher, fructose was selected as carbon source for further studies. Minimum biomass and PHB were obtained with $20 \mathrm{~g} / \mathrm{L}-$ Arabinose. Previous data in the bioreactor showed that both growth and PHB production rates were slower on pentoses than on hexoses (Bertrand et al. 1990). Naturally occurring strains of $C$. necator have been reported to utilize only fructose as carbon source (Raje and Srivastava 1998). Therefore, for further optimization studies, fructose was used as carbon source.

Analysis of final $\mathrm{pH}$ confirms strong buffering capacity of our culture. In all experiments with different carbon sources, the cell growth and PHB production occur without changing $\mathrm{pH}$ significantly.

The effect of different nitrogen sources on growth and PHB production

Production of PHB by $C$. necator on different nitrogen sources was followed using MSM with fructose as a carbon source. Six different nitrogen sources were selected at concentration of $2 \mathrm{~g} / \mathrm{L}$. The results are shown in Table 2 and indicate that ammonium chloride produced the highest amount of PHB followed by yeast extract. The PHB content was relatively the same when urea, peptone, ammonium sulfate, and tryptone were used. However, the final biomass is lower in the presence of ammonium sulfate. This in contrast to the study of Koutinas et al. (2007) reported that ammonium sulfate is the best nitrogen source for the PHB production of $C$. necator. Also, other studies showed that Azotobacter vinelandii UWD strain PHB production increases in complex nitrogen sources, which is not applicable here (Page 1992). Because of these results, the ammonium chloride salt was used as a nitrogen source 
Table 2 Biomass and PHB production obtained with different nitrogen sources after $48 \mathrm{~h}$

\begin{tabular}{llll}
\hline Nitrogen source & Biomass $(\mathrm{g} / \mathrm{L})$ & PHB $(\mathrm{g} / \mathrm{L})$ & Final $\mathrm{pH}$ \\
\hline Peptone & 3.24 & 0.36 & 8.32 \\
Tryptone & 3.34 & 0.31 & 8.25 \\
Yeast extract & 4.1 & 0.59 & 8.1 \\
Urea & 3.6 & 0.303 & 8.245 \\
$\left(\mathrm{NH}_{4}\right)_{2} \mathrm{SO}_{4}$ & 2.04 & 0.35 & 8.005 \\
$\mathrm{NH}_{4} \mathrm{Cl}$ & 5.6 & 0.66 & 5.185 \\
\hline
\end{tabular}

in the following studies. According to the final $\mathrm{pH}, \mathrm{pH}$ values in this experiment decrease significantly, but it seems that it did not greatly affect the growth or production of PHB by the $C$. necator. This result is also in contrast with the results of Beaulieu et al. (1995) and Repaske (1962) who reported that (in the absence of $\mathrm{pH}$ control) at an ammonium concentration higher than $0.5 \mathrm{~g} / \mathrm{L}$, the growth of $C$. necator rapidly stopped when the $\mathrm{pH}$ dropped below 5.4 .

\section{Plackett-Burman design}

Prior to optimization, it is necessary to use Plackett-Burman experiments that highlighted the importance of optimizing culture variables in attaining higher PHB production rate. In order to select significant variables for PHB production, a variety of factors including nutrients (fructose, $\mathrm{KH}_{2} \mathrm{PO}_{4}, \mathrm{NH}_{4} \mathrm{Cl}$, and trace element), physical ( $\mathrm{pH}$ and agitation speed), and cultivation parameters (inoculum size) were tested and identified via PlackettBurman design experiment (Table 3). The software used in the study was Design Expert 7.0.0 (Stat-Ease, Inc., Minneapolis, MN, USA). Seven factors were screened in sixteen combinations, and all the experiments were performed in duplicate, and average of the observation was used as the response of the design. Table 4 shows the distribution of the factors in the experiment according to the design expert software and the response in the study. Table 5 presents $p$ values for the effect of medium components on biomass and PHB production. It is apparent from the table that $\mathrm{pH}$, agitation speed, fructose, and $\mathrm{KH}_{2} \mathrm{PO}_{4}$ showed significant influence on PHB accumulation when considered as individual process variable $(p<0.05)$. Of the seven factors (A-F), except inoculums percentage, ammonium chloride, and trace element concentration, all others were taken for optimization, since the $p$ value of them is greater than 0.05 . On analysis of regression coefficient of sixteen medium components, fructose and agitation speed showed positive effect for $\mathrm{PHB}$ production, whereas $\mathrm{KH}_{2} \mathrm{PO}_{4}$ and initial $\mathrm{pH}$ showed negative effect in the tested range. From Table 4, it can also be seen that PHB production was a maximum when $\mathrm{KH}_{2} \mathrm{PO}_{4}$ was minimum (Experiments 7), and
Table 3 Different variables at different levels used for PlackettBurman design

\begin{tabular}{lll}
\hline Factor & Lower & Higher \\
\hline Fructose $(\mathrm{g} / \mathrm{L})$ & 5 & 25 \\
$\mathrm{NH}_{4} \mathrm{Cl}(\mathrm{g} / \mathrm{L})$ & 1 & 6 \\
$\mathrm{KH}_{2} \mathrm{PO}_{4}(\mathrm{~g} / \mathrm{L})$ & 0.5 & 3 \\
Inoculum (\%) & 5 & 10 \\
Trace element (mL/L) & 5 & 15 \\
Agitation Speed (rpm) & 100 & 250 \\
Initial pH & 6 & 8 \\
\hline
\end{tabular}

fructose and agitation speed are maximum. In this connection, Cavaillé et al. (2013) reported that PHB accumulation was enhanced when growth was restricted due to unavailability of phosphorus. However, their contribution to biomass production is also important. However, the study presented here succeeded in producing $31.6 \%$ PHB, regarding to the cell dry weight. In this context, PHB content in $C$. necator cells varied from 3.6 to $30.5 \%$ PHB. This means that the method used herein is a successful method for increasing PHB content.

Optimization by response surface methodology

The next step in the optimization of the medium was to determine the optimum levels of significant variables for PHB production. For this purpose, CCD was used to optimize the most significant factors affecting PHB production obtained from Plackett-Burman. Response surface methodology is a successive, exploratory approach to establish the relationship between more than one variable with the obtained responses. The analysis develops a model by fitting the experimental data in a generalized smooth curve, from which a specific predicted response could be calculated (Elibol 2004).

Base on the Plackett-Burman design, the significant variables utilized were as follows: fructose, $\mathrm{KH}_{2} \mathrm{PO}_{4}$, agitation speed, and initial $\mathrm{pH}$. The experiments conducted in the present study were targeted toward the construction of a quadratic model consisting of 30 trials. The minimum and maximum ranges of the variables were used, and the full experimental plan with regard to their values in actual form is provided in Table 6 . The PHB production in each experiment was the average of the duplicates. The results were analyzed by Design Expert Software, and PHB production and biomass can be expressed in terms of the following equations:

$$
\begin{aligned}
\mathrm{PHB}= & +3.10+1.88 \mathrm{~A}-0.25 \mathrm{~B}+0.26 \mathrm{C}+0.47 \mathrm{D} \\
& +0.27 \mathrm{AB}-0.12 \mathrm{AC}+0.62 \mathrm{AD}-0.090 \mathrm{BC} \\
& +0.47 \mathrm{BD}-0.049 \mathrm{CD}+0.21 \mathrm{~A}^{2}-0.27 \mathrm{~B}^{2} \\
& -0.33 \mathrm{C}^{2}-0.43 \mathrm{D}^{2}
\end{aligned}
$$


Table 4 Experimental design and response of Plackett-Burman study

\begin{tabular}{|c|c|c|c|c|c|c|c|c|c|c|}
\hline $\begin{array}{l}\text { Experiment } \\
\text { No. }\end{array}$ & $\begin{array}{l}\text { Fructose } \\
(\mathrm{g} / \mathrm{L})\end{array}$ & $\begin{array}{l}\mathrm{NH}_{4} \mathrm{Cl} \\
(\mathrm{g} / \mathrm{L})\end{array}$ & $\begin{array}{l}\mathrm{KH}_{2} \mathrm{PO}_{4} \\
(\mathrm{~g} / \mathrm{L})\end{array}$ & $\begin{array}{l}\text { Inoculum } \\
(\%)\end{array}$ & $\begin{array}{l}\text { Trace element } \\
(\mathrm{mL} / \mathrm{L})\end{array}$ & $\begin{array}{l}\text { Agitation } \\
\text { speed (rpm) }\end{array}$ & $\begin{array}{l}\text { Initial } \\
\mathrm{pH}\end{array}$ & $\begin{array}{l}\text { PHB } \\
(\mathrm{g} / \mathrm{L})\end{array}$ & $\begin{array}{l}\text { Biomass } \\
(\mathrm{g} / \mathrm{L})\end{array}$ & $\begin{array}{l}\text { PHB \% } \\
\text { accumulation }\end{array}$ \\
\hline 1 & 5.00 & 6.00 & 3.00 & 10.00 & 5.00 & 100.00 & 6 & 0.207765 & 2.84 & 7.315659 \\
\hline 2 & 25.00 & 1.00 & 3.00 & 10.00 & 5.00 & 250 & 8 & 0.843294 & 4.42 & 19.07905 \\
\hline 3 & 25.00 & 1.00 & 3.00 & 10.00 & 15.00 & 100 & 6 & 0.261176 & 3.02 & 8.648228 \\
\hline 4 & 5.00 & 6.00 & 3.00 & 5.00 & 15.00 & 250 & 8 & 0.05 & 1.12 & 4.464286 \\
\hline 5 & 15.00 & 3.50 & 1.75 & 7.50 & 10.00 & 175 & 7 & 0.256941 & 5.46 & 4.705882 \\
\hline 6 & 25.00 & 6.00 & 3.00 & 5.00 & 5.00 & 100 & 8 & 0.265765 & 1.32 & 20.13369 \\
\hline 7 & 25.00 & 6.00 & 0.50 & 10.00 & 15.00 & 250 & 6 & 1.64706 & 5.4 & 30.50109 \\
\hline 8 & 25.00 & 1.00 & 0.50 & 5.00 & 15.00 & 100 & 8 & 0.264471 & 2.24 & 11.80672 \\
\hline 9 & 5.00 & 1.00 & 0.50 & 5.00 & 5.00 & 100 & 6 & 0.139294 & 2.12 & 6.570477 \\
\hline 10 & 5.00 & 1.00 & 0.50 & 10.00 & 5.00 & 250 & 8 & 0.160424 & 2.44 & 6.574735 \\
\hline 11 & 25.00 & 6.00 & 0.50 & 5.00 & 5.00 & 250 & 6 & 0.852706 & 3.96 & 21.53298 \\
\hline 12 & 15.00 & 3.50 & 1.75 & 7.50 & 10.00 & 175 & 7 & 0.421647 & 5.64 & 7.476012 \\
\hline 13 & 5.00 & 1.00 & 3.00 & 5.00 & 15.00 & 250 & 6 & 0.293647 & 2.82 & 10.41302 \\
\hline 14 & 15.00 & 3.50 & 1.75 & 7.50 & 10.00 & 175 & 7 & 0.256941 & 4.98 & 5.159461 \\
\hline 15 & 5.00 & 6.00 & 0.50 & 10.00 & 15.00 & 100 & 8 & 0.05 & 1.38 & 3.623188 \\
\hline 16 & 15.00 & 3.50 & 1.75 & 7.50 & 10.00 & 175 & 7 & 0.213647 & 4.34 & 4.922743 \\
\hline
\end{tabular}

Table $5 p$ value, coefficient, and standard error for the effect of medium components on growth and PHB production

\begin{tabular}{llll}
\hline Factors & $p$ values & Coefficient & Standard error \\
\hline Fructose $(\mathrm{g} / \mathrm{L})$ & $0.0047^{\mathrm{b}}$ & 0.27 & 0.066 \\
$\mathrm{NH}_{4} \mathrm{Cl}(\mathrm{g} / \mathrm{L})$ & $0.2041^{\mathrm{a}}$ & 0.093 & 0.066 \\
$\mathrm{KH}_{2} \mathrm{PO}_{4}(\mathrm{~g} / \mathrm{L})$ & $0.0966^{\mathrm{c}}$ & -0.099 & 0.066 \\
Inoculum $^{(\%)}$ & $0.1443^{\mathrm{a}}$ & 0.11 & 0.066 \\
Trace element (mL/L) & $0.9060^{\mathrm{a}}$ & $8.092 \mathrm{E}-0.03$ & 0.066 \\
Agitation speed (rpm) & $0.0122^{\mathrm{b}}$ & 0.22 & 0.066 \\
Initial $\mathrm{pH}$ & $0.0611^{\mathrm{c}}$ & -0.15 & 0.066
\end{tabular}

${ }^{a}$ Nonsignificant at $p<0.05$

b Significant positive effect

c Significant negative effect

Biomass $=+6.47+2.27 \mathrm{~A}-0.172 \mathrm{~B}+0.416 \mathrm{C}+0.739 \mathrm{D}$

$$
\begin{aligned}
& -0.0913 \mathrm{AB}-0.279 \mathrm{AC}+0.389 \mathrm{AD} \\
& -0.299 \mathrm{BC}-0.149 \mathrm{BD}-0.221 \mathrm{CD}+0.204 \mathrm{~A}^{2} \\
& -0.856 \mathrm{~B}^{2}-0.374 \mathrm{C}^{2}-0.541 \mathrm{D}^{2}
\end{aligned}
$$

In which, $\mathrm{A}$ is fructose, $\mathrm{B}$ is initial $\mathrm{pH}, \mathrm{C}$ is $\mathrm{KH}_{2} \mathrm{PO}_{4}$, and $\mathrm{D}$ is agitation speed.

In order to determine the optimal levels of each variable for maximum PHB production, three-dimensional response surface plots were constructed by plotting the response (PHB production or biomass) on the Z-axis against any two variables which their interaction are most significant (according to their $p$ values) while maintaining other variables at their optimal levels (Figs. 2, 3). Fructose and agitation speed showed significant influence on PHB accumulation either as individual or in interaction with each other $(p<0.0001)$. The results indicate that the concentration of the carbon source bears a direct relationship with PHB production. The 3D plot (Figs. 2, 3) clearly shows a linear increase in PHB production and biomass when the fructose concentrations were increased. The $p$ values for the model $(<0.0001)$ and for lack of fit $(<0.0001)$ for biomass and PHB production also suggested that the obtained experimental data were a good fit with the model.

It was found by perturbation plot (Fig. 4) that PHB accumulation enhanced up to agitation speed of $175 \mathrm{rpm}$, but from 175 to 250 , this increase is gradual and has no significant effect on PHB production. This is in contrast to previous studies, which reported agitation speed higher than $200 \mathrm{rpm}$ showed negative influence on PHB content (Khosravi Darani et al. 2004). The best values for $\mathrm{KH}_{2} \mathrm{PO}_{4}$ and agitation speed as one parameter were $1.75 \mathrm{~g} / \mathrm{L}$ and $175 \mathrm{rpm}$, respectively. The PHB content decreases when initial $\mathrm{pH}$ increases from 6 to 8 (Figs. 1,2). This may be the reason that ammonium chloride was the best nitrogen source because it could decrease the $\mathrm{pH}$ of medium, although the important matter here is the effect of factors in combination with each other.

From the CCD results, it was found that PHB content increased from $1.03 \mathrm{~g} / \mathrm{L}$ using Plackett-Burman design to $7.48 \mathrm{~g} / \mathrm{L}$. Thus, the optimum values of the media 
Table 6 Experimental design and response of Central composite design

\begin{tabular}{|c|c|c|c|c|c|c|c|}
\hline $\begin{array}{l}\text { Experiment } \\
\text { No. }\end{array}$ & $\begin{array}{l}\text { Fructose } \\
\text { (A) }(\mathrm{g} / \mathrm{L})\end{array}$ & $\begin{array}{l}\text { Initial } \\
\text { pH (B) }\end{array}$ & $\begin{array}{l}\mathrm{KH}_{2} \mathrm{PO}_{4} \\
\text { (C) }(\mathrm{g} / \mathrm{L})\end{array}$ & $\begin{array}{l}\text { Agitation } \\
\text { speed (D) }\end{array}$ & $\begin{array}{l}\text { PHB } \\
(\mathrm{g} / \mathrm{L})\end{array}$ & $\begin{array}{l}\text { Biomass } \\
(\mathrm{g} / \mathrm{L})\end{array}$ & $\begin{array}{l}\text { PHB \% } \\
\text { accumulation }\end{array}$ \\
\hline 1 & 5.00 & 6 & 0.5 & 100 & 0.706975 & 2.72 & 25.99173 \\
\hline 2 & 25.00 & 6 & 0.5 & 100 & 3.625725 & 6.38 & 56.82955 \\
\hline 3 & 5.00 & 6 & 3 & 100 & 1.095725 & 3.22 & 34.02873 \\
\hline 4 & 25.00 & 6 & 3 & 100 & 3.935725 & 7.24 & 54.36084 \\
\hline 5 & 5.00 & 8 & 0.5 & 100 & 0.3301 & 2.7 & 12.22593 \\
\hline 6 & 25.00 & 8 & 0.5 & 100 & 2.741975 & 5.96 & 46.00629 \\
\hline 7 & 5.00 & 8 & 3 & 100 & 0.526975 & 3.1 & 16.99919 \\
\hline 8 & 25.00 & 8 & 3 & 100 & 2.498225 & 6.42 & 38.91316 \\
\hline 9 & 5.00 & 6 & 0.5 & 250 & 0.1726 & 2.72 & 6.345588 \\
\hline 10 & 25.00 & 6 & 0.5 & 250 & 4.275725 & 7.76 & 55.09955 \\
\hline 11 & 5.00 & 6 & 3 & 250 & 0.814475 & 4.02 & 20.26057 \\
\hline 12 & 25.00 & 6 & 3 & 250 & 3.913225 & 7.94 & 49.28495 \\
\hline 13 & 5.00 & 8 & 0.5 & 250 & 0.171975 & 2.74 & 6.27646 \\
\hline 14 & 25.00 & 8 & 0.5 & 250 & 6.763225 & 10.38 & 65.15631 \\
\hline 15 & 5.00 & 8 & 3 & 250 & 0.1476 & 3.22 & 4.583851 \\
\hline 16 & 25.00 & 8 & 3 & 250 & 6.375725 & 7.1 & 89.79894 \\
\hline 17 & -5.00 & 7 & 1.75 & 175 & 0.0501 & 1.68 & 2.982143 \\
\hline 18 & 35.00 & 7 & 1.75 & 175 & 7.481975 & 11.6 & 64.49978 \\
\hline 19 & 15.00 & 7 & -0.75 & 175 & 0.143225 & 2.06 & 6.95267 \\
\hline 20 & 15.00 & 7 & 4.25 & 175 & 3.050725 & 6.6 & 46.22311 \\
\hline 21 & 15.00 & 5 & 1.75 & 175 & 3.613225 & 4.01 & 90.10536 \\
\hline 22 & 15.00 & 9 & 1.75 & 175 & 0.0656 & 1.46 & 4.493151 \\
\hline 23 & 15.00 & 7 & 1.75 & 25 & 0.176038 & 1.26 & 13.97123 \\
\hline 24 & 15.00 & 7 & 1.75 & 325 & 2.225725 & 6.06 & 36.72814 \\
\hline 25 & 15.00 & 7 & 1.75 & 175 & 3.213225 & 6.46 & 49.74033 \\
\hline 26 & 15.00 & 7 & 1.75 & 175 & 3.081975 & 6.3 & 48.92024 \\
\hline 27 & 15.00 & 7 & 1.75 & 175 & 3.269475 & 6.7 & 48.79813 \\
\hline 28 & 15.00 & 7 & 1.75 & 175 & 2.906975 & 6.38 & 45.56387 \\
\hline 29 & 15.00 & 7 & 1.75 & 175 & 3.069475 & 6.46 & 47.51509 \\
\hline 30 & 15.00 & 7 & 1.751 & 175 & 3.038225 & 6.52 & 46.59854 \\
\hline
\end{tabular}

Design-Expert@ Software

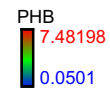

$\mathrm{X} 1=\mathrm{A}:$ Fructose $\mathrm{X} 2=\mathrm{D}:$ agitation speed

Actual Factors B: Initial $\mathrm{pH}=7.00$
$\mathrm{C}: \mathrm{kH} 2 \mathrm{PO} 4=1.75$

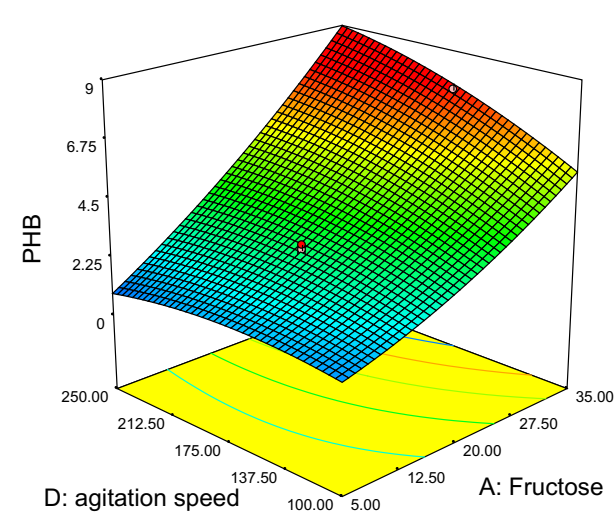

Fig. 2 3D surface showing the interactive effect of fructose $(\mathrm{g} / \mathrm{L})$ and agitation speed (rpm) on PHB content $(\mathrm{g} / \mathrm{L})$ after $48 \mathrm{~h}$ of cultivation
Design-Expert® Software

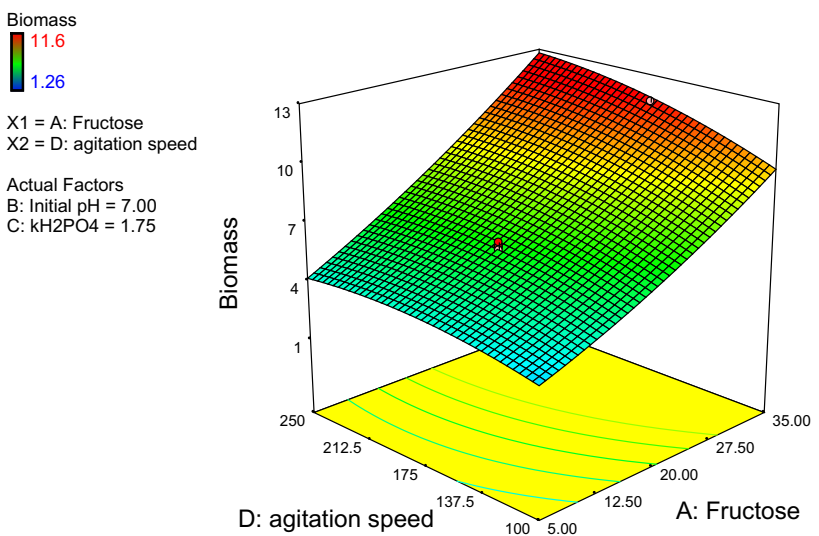

Fig. 3 3D surface showing the interactive effect of fructose $(\mathrm{g} / \mathrm{L})$ and agitation speed $(\mathrm{rpm})$ on biomass $(\mathrm{g} / \mathrm{L})$ after $48 \mathrm{~h}$ of cultivation 


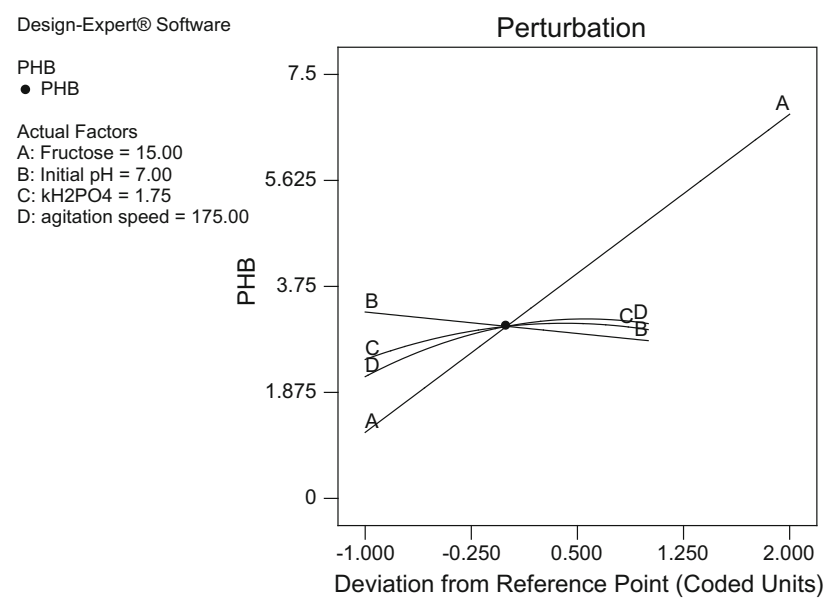

Fig. 4 Perturbation plot showing the effect of fructose, agitation speed, initial $\mathrm{pH}$, and $\mathrm{KH}_{2} \mathrm{PO}_{4}$ on $\mathrm{PHB}$ content after $48 \mathrm{~h}$ of cultivation

components (Table 6) after CCD design are as follows: fructose, $35 \mathrm{~g} / \mathrm{L}, \mathrm{KH}_{2} \mathrm{PO}_{4}, 1.75 \mathrm{~g} / \mathrm{L}, \mathrm{MgSO}_{4} .7 \mathrm{H}_{2} \mathrm{O} 1.2 \mathrm{~g} /$ $\mathrm{L}$, Citric acid $1.7 \mathrm{~g} / \mathrm{L}$, trace element $10 \mathrm{~mL} / \mathrm{L} \mathrm{m}$ initial $\mathrm{pH}=7$, and agitation speed 175 . This is the characteristic of CCD, which designs some runs up or down to limitation values. In these experiments, it is found that higher value of PHB can be reached by increasing fructose concentration up to limitation. This is the case that needs more evaluation. After knowing the possible direction for maximizing PHB production, the optimization was done by "Point prediction" technique. A maximum PHB content of $7.70 \mathrm{~g} /$ $\mathrm{L}$ was predicted that was near to what reported $(7.48 \mathrm{~g} / \mathrm{L})$.

\section{Conclusion}

The methodology of Plackett-Burman was very useful for the short-listing of relevant variables for process optimization. Using the method of factorial design and response surface analysis, it was possible to determine optimal operating conditions, which led to higher concentrations and productivity without any loss of yield. Shake flask cultivation studies depicted $7.48 \mathrm{~g} / \mathrm{L}$ PHB content under optimized nutrient and physical variables, which is higher than the previous report under similar condition (Tripathi et al. 2013). Optimized media obtained by response surface methodology consisted of fructose, $35 \mathrm{~g} / \mathrm{L} ; \mathrm{KH}_{2} \mathrm{PO}_{4}$, $1.75 \mathrm{~g} / \mathrm{L} ; \mathrm{MgSO}_{4} \cdot 7 \mathrm{H}_{2} \mathrm{O} 1.2 \mathrm{~g} / \mathrm{L}$, Citric acid $1.7 \mathrm{~g} / \mathrm{L}$, trace element $10 \mathrm{~mL} / \mathrm{L}$, initial $\mathrm{pH}=7$, agitation speed 175 , and temperature $30{ }^{\circ} \mathrm{C}$. In this study, fructose and agitation speed showed significant effect on PHB content. However,
PHB production can be controlled by precisely manipulating $\mathrm{pH}$ and phosphorous source.

These data obtained from batch culture would be used for simulation of nutrient feeding strategies in fed batch/ continuous cultivation for over production of PHB. The possible explanation for the rise in PHB pool with increasing amount of fructose is due to boost in growth and the availability of plenty of precursors, i.e., acetate for biosynthesis of PHB, as reported in many bacteria (Zinn et al. 2003; Galindo et al. 2007). These results show that Plackett-Burman design not only is able to optimize the nutritional constituents, but also the physical variables. On the basis of the data obtained in the present study, C. necator is capable of PHB accumulation up to $90 \%$ of dry cell weight. PHB accumulation was induced by phosphate limitation instead of nitrogen limitation. In this connection, Cavaillé et al. (2013) reported that PHB accumulation was enhanced when growth was restricted due to unavailability of phosphorus. Using byproducts that are rich in fructose such as palm date powder or fruit juice for making the process of production cost-effective and some molecular studies are needed to increase more PHB content and making it cost-effective.

Acknowledgments The authors would like to thank the research council of Malek-Ashtar University of Technology for the financial support of this investigation.

\section{Abbreviations}

$\begin{array}{ll}\text { PHA } & \text { Polyhydroxyalkanoate } \\ \text { PHB } & \text { Polyhydroxybutyrate } \\ \text { CCD } & \text { Central composite design } \\ \text { RSM } & \text { Response surface methodology }\end{array}$

\section{References}

Anderson-Cook CM, Borror CM, Montgomery DC (2009) Response surface design evaluation and comparison. J Stat Plan Inference 139:629-641

Arun A, Murrugappan RM, Ravindran AVD, Veeramaniknandan V, Balaji S (2006) Utilization of various industrial wastes for the production of poly-b-hydroxy butyrate (PHB) by Alcaligenes eutrophus. Afr J Biotechnol 5(17):1524-1527

Beaulieu M, Beaulieu Y, Mélinard J, Pandian S, Goulet J (1995) Influence of ammonium salts and cane molasses on growth of Alcaligenes eutrophus and production of polyhydroxybutyrate. Appl Environ Microbiol 61:165-169

Bertrand JL, Ramsay BA, Ramsay JA, Chavarria C (1990) Biosynthesis of poly- $\beta$-hydroxyalkanoates from pentoses by Pseudomonas pseudoflava. Appl Environ Microbiol 56(10):3133-3138

Burdon KL (1946) Fatty materials in bacteria and fungi revealed by staining dried, fixed slide preparations. J Bacteriol 52:665-678 
Cavaillé L, Grousseau E, Pocquet M, Lepeuple AS, Uribelarrea JL, Hernandez-Raquet G, Paul E (2013) Polyhydroxybutyrate production by direct use of waste activated sludge in phosphoruslimited fed-batch culture. Bioresour Technol 149:301-309

Cavalheiro JMBT, de Almeida MCMD, Grandfils C, da Fonseca MMR (2009) Poly (3-hydroxybutyrate) production by Cupriavidus necator using waste glycerol. Process Biochem 44:509-515

Chen GQ (2005) Polyhydroxyalkanoates. In: Smith RFL (ed) Biodegradable polymers for industrial applications. CRC Press, Boca Raton

Chen GQ, Qiong W (2005) The application of polyhydroxyalkanoates as tissue engineering materials. Biomaterials 26:6565-6578

Colak F, Atar N, Olgun A (2009) Biosorption of acidic dyes from aqueous solution by Paenibacillus macerans: kinetic, thermodynamic and equilibrium studies. Chem Eng J 150:122-130

Colak F, Atar N, Yazıcıoglua D, Olgun A (2011) Biosorption of lead from aqueous solutions by Bacillus strains possessing heavymetal resistance. Chem Eng J 173:422-428

De Almeida A, Giordano AM, Nikel PI, Pettinari MJ (2010) Effects of aeration on the synthesis of poly(3-hydroxybutyrate) from glycerol and glucose in recombinant Escherichia coli. Appl Environ Microbiol 76:2036-2040

Elibol M (2004) Optimization of medium composition for actinorhodin production by Streptomyces coelicolor A3 (2) with response surface methodology. Process Biochem 39:1057-1062

Flieger M, Kantorova M, Prell A, Rezanka T, Votruba J (2003) Biodegradable plastics from renewable sources. Folia Microbiol 48(2):27-44

Frey DD, Engelhardt F, Greitzer EM (2003) A role for "one-factorat-a-time"' experimentation in parameter design. Res Eng Des 14:65-74

Galgani F, Leaute JP, Moguedet P, Souplet A, Verin Y, Carpentier A, Goraguer H, Latrouite D, Andral B, Cadiou Y, Mahe JC, Poulard JC, Nerisson P (2000) Litter on the sea floor along European coasts. Mar Pollut Bull 40:516-527

Galindo E, Peña C, Núñez C, Segura D, Espin G (2007) Molecular and bioengineering strategies to improve alginate and polyhydroxyalkanoate production by Azotobacter vinelandii. Microb Cell Fact 6:1-16

Gregory MR (2009) Environmental implications of plastic debris in marine settings-entanglement, ingestion, smothering, hangerson, hitch-hiking and alien invasions. Philos Trans R Soc B 364:2013-2025

Gupta VK, Atar N, Yola ML, Darcan C, Idil O, Ustundag Z, Suhas (2013) Biosynthesis of silver nanoparticles using chitosan immobilized Bacillus cereus: nanocatalytic studies. J Mol Liq 188:81-88

Ivanov V, Stabnikov V, Ahmed Z, Dobrenko S, Saliuk A (2014) Production and applications of crude polyhydroxyalkanoate containing bioplastic from the organic fraction of municipal solid waste. Int J Environ Sci Technol 12:725-738

Jung YM, Park JS, Lee YH (2000) Metabolic transformation of cloned $p h b C A B$ genes for the investigation of the regulatory mechanism of polyhydroxyalkanoate biosynthesis. Enz Microb Technol 26:201-208

Khanna S, Srivastava AK (2005) Statistical media optimization studies for growth and PHB production by Ralstonia eutropha. Process Biochem 4:2173-2183

Khosravi Darani K, Vasheghani Farahani E, Shoja Alsadati SA (2004) Application of the Taguchi design for production of poly(b-hydroxybutyrate) by Ralstonia eutropha. Iran J Chem Chem Eng 23:131-136
Kim BS, Lee SC, Lee SY, Chang HN, Chang YK, Woo SI (1994a) Production of poly (3-hydroxybutyric- co-3-hydroxyvaleric acid) by fed-batch culture of Alcaligenes eutrophus with substrate control using online glucose analyzer. Enz Microb Technol 16:556-561

Kim BS, Lee SC, Lee SY, Chang HN, Chang YK, Woo SI (1994b) Production of poly (3-hydroxybutyric acid) by fed-batch culture of Alcaligenes eutrophus with glucose concentration control. Biotechnol Bioeng 43:892-898

Koutinas AA, Xu Y, Wang R, Webb C (2007) Polyhydroxybutyrate production from a novel feedstock derived from a wheat-based biorefinery. Enz Microb Technol 40:1035-1044

Liu JG, Xing JM, Chang TS, Ma ZY, Liu HZ (2005) Optimization of nutritional conditions for nattokinase production by Bacillus natto NLSSE using statistical experimental methods. Process Biochem 40:2757-2762

Md Din MF, Ponraj M, Van Loosdrecht M, Ujang Z, Chelliapan S, Zambare V (2014) Utilization of palm oil mill effluent for polyhydroxyalkanoate production and nutrient removal using statistical design. Int J Environ Sci Technol 11:671-684

Mu WM, Chen C, Li XF, Zhang T, Jiang B (2009) Optimization of culture medium for the production of phenyllactic acid by Lactobacillus sp. SK007. Bioresource Technol 100:1366-1370

Mumtaz T, Khanc MR, Hassana ML (2010) Study of environmental biodegradation of LDPE films in soil using optical and scanning electron microscopy. Micron 41:430-438

Owen HR, Wengerd D, Miller AR (1991) Culture medium pH is influenced by basal medium, carbohydrate source, gelling agent, activated charcoal, and medium storage method. Plant Cell Rep 10:583-586

Page WJ (1992) Production of poly-b-hydroxybutyrate by Azotobacter vinelandii UWD in media containing sugars and complex nitrogen sources. Appl Microbiol Biotechnol 38:117-121

Poirier Y (1999) Production of new polymeric compounds in plants. Plant Biotechnol 10:181-185

Raje P, Srivastava AK (1998) Poly (3-hydroxybutyrate) synthesis in fed-batch culture of Ralstonia eutropha with phosphate limitation under different glucose concentrations. Bioresour Technol 64:185-192

Repaske R (1962) Nutritional requirements for Hydrogenomonas eutropha. J Bacteriol 83:418-422

Sandhya M, Aravind J, Kanmani P (2013) Production of polyhydroxyalkanoates from Ralstonia eutropha using paddy straw as cheap substrate. Int J Environ Sci Technol 10:47-54

Shang L, Jiang M, Chang HN (2003) Poly (3-hydroxybutyrate) synthesis in fed-batch culture of Ralstonia eutropha with phosphate limitation under different glucose concentrations. Biotechnol Lett 25:1415-1419

Singh P, Parmar N (2011) Isolation and characterization of two novel polyhydroxybutyrate (PHB)-producing bacteria. Afr J Biotech 10:4907-4919

Tripathi AD, Srivastava SK, Singh RP (2013) Statistical optimization of physical process variables for bio-plastic (PHB) production by Alcaligenes sp. Biomass Bioenerg 55:243-250

Wang YW, Wu Q, Chen GQ (2005) Gelatin blending improves the performance of poly(3-hydroxybutyrate-co-3-hydroxyhexanoate) films for biomedical application. Biomacromolecules 6:566-571

Wei YH, Chen WC, Huang CK, Wu HS, Sun YM, Lo CW, Janarthanan OM (2011) Screening and evaluation of polyhydroxybutyrate producing strains from indigenous isolate Cupriavidus taiwanensis strains. Int J Mol Sci 12:252-265 
Xu H, Sun LP, Shi YZ, Wu YH, Zhang B, Zhao DQ (2008) Optimization of cultivation conditions for extracellular polysaccharide and mycelium biomass by Morchella esculenta As51620. Biochem Eng J 39:66-73
Zinn M, Weilenmann H, Hany R, Schmid M, Egli T (2003) Tailored synthesis of poly-R- $\beta$-hydroxybutyrate-co-hydroxyvalerate (PHB/HV) in Ralstonia euthropha DSM 428. Acta Biotechnol 23:309-316 